\title{
NEW ZINC OXALATO AND HYDROGENOXALATO COMPLEXES: SYNTHESIS AND INFRARED STUDY
}

\author{
GORGUI AWA SECK ${ }^{1}$, LIBASSE DIOP ${ }^{1 *}$, ABOUBACRY SENE ${ }^{1}$ \\ ${ }^{1}$ University Cheikh Anta Diop, Faculty of Sciences and Technics, Department of Chemistry, \\ Laboratory of Mineral and Analytical Chemistry, DAKAR, Senegal
}

\begin{abstract}
Five new oxalato and hydrogenoxalato complexes with $\mathrm{ZnBr}_{2}$ have been synthesized and studied by infrared. Discrete structures have been suggested in the basis of spectroscopic data. The environments around the zinc centre being trigonal bipyramidal, tetrahedral, octahedral or monocapped octahedral. The anions behave as monochelating ligands. When the cations and $\mathrm{OH}$ group are involved in extra hydrogen bonds, a supramolecular architecture may be obtained.
\end{abstract}

Keywords: discrete structures, hydrogen bonds, IR technic, monochelating oxoanions, monocapped octahedral, oxalato and hydrogenoxalato complexes

\section{INTRODUCTION}

Hathaway [1] has summarized the data on the coordination ability of oxyanions; our group and many other research groups worldwide have published several papers on this topic [2-8]. In this dynamic we initiate here the study of the interactions between $\left(\mathrm{Et}_{3} \mathrm{NH}\right) \mathrm{HC}_{2} \mathrm{O}_{4}$ or $\left(\mathrm{Et}_{3} \mathrm{NH}\right)_{2} \mathrm{C}_{2} \mathrm{O}_{4}$ and $\mathrm{ZnBr}_{2}$ which has yielded five new complexes, infrared study of which have been carried out then structures suggested on the basis of spectroscopic data.

\section{EXPERIMENTAL SETUP}

$\left(\mathrm{Et}_{3} \mathrm{NH}\right) \mathrm{HC}_{2} \mathrm{O}_{4}\left(\mathbf{L}_{1}\right)$-[\%Calculated (\% Found): \% $\left.\mathbf{C}=50.25(50.19), \% \mathbf{H}=8.96(8.67), \% \mathbf{N}=7.32(7.42)\right]-$ and $\left(\mathrm{Et}_{3} \mathrm{NH}\right)_{2} \mathrm{C}_{2} \mathrm{O}_{4}\left(\mathbf{L}_{2}\right)-[\% \mathbf{C}=57.50(57.10), \% \mathbf{H}=11.03(10.87), \% \mathbf{N}=9.58(9.53)$, have been obtained as crystals on semi-or totally neutralizing oxalic acid with $\mathrm{Et}_{3} \mathrm{~N}$ in water and allowing the obtained solution to evaporate in the oven at $60^{\circ} \mathrm{C}$.

When (L1) is allowed to react with $\mathrm{ZnBr}_{2}$ in ethanol in the ratio $2 / 1$ for $\mathbf{A}, 1 / 1$ for $\mathbf{B}$, and $1 / 2$ for $\mathbf{C}$, white powders are collected after a slow solvent evaporation. When ethanolic solutions of $\left(\mathrm{L}_{2}\right)$ are allowed to react with $\mathrm{ZnBr} 2$ in $1 / 1$ ratio for $\mathrm{D}$ and $2 / 1$ for $\mathrm{E}$, white precipitates are obtained, stirred around two hours and filtered. The analytical data [\% Calculated (\% Found)], (Table 1), have allowed suggesting the following formulaes:
A: $\left(\mathrm{Et}_{3} \mathrm{NH}\right) \mathrm{HC}_{2} \mathrm{O}_{4} \cdot \mathrm{Zn}\left(\mathrm{HC}_{2} \mathrm{O}_{4}\right)_{2} \cdot 1 / 4 \mathrm{Et}_{3} \mathrm{NHBr}$
B: $\left(\mathrm{Et}_{3} \mathrm{NH}\right) \mathrm{HC}_{2} \mathrm{O}_{4} \cdot \mathrm{ZnBr}_{3} \mathrm{HNEt}_{3} \cdot 2 \mathrm{H}_{2} \mathrm{O}$
C: $\left(\mathrm{Et}_{3} \mathrm{NH}\right) \mathrm{HC}_{2} \mathrm{O}_{4} \cdot \mathrm{Et}_{3} \mathrm{NHBr} \cdot \mathrm{Zn}\left(\mathrm{HC}_{2} \mathrm{O}_{4}\right)_{2} \cdot 1 / 8 \mathrm{Et}_{3} \mathrm{NHBr}$

\footnotetext{
* Corresponding author, email: dlibasse@gmail.com

(C) 2017 Alma Mater Publishing House
} 


\section{D: $\left(\mathrm{Et}_{3} \mathrm{NH}\right)_{2} \mathrm{C}_{2} \mathrm{O}_{4} \cdot \mathrm{ZnC}_{2} \mathrm{O}_{4} \cdot \mathrm{ZnBr}_{2} \cdot \mathrm{Et}_{3} \mathrm{NHBr}$. $\mathrm{EtOH}$ \\ E: $\left(\mathrm{Et}_{3} \mathrm{NH}\right)_{2} \mathrm{C}_{2} \mathrm{O}_{4} \cdot \mathrm{ZnC}_{2} \mathrm{O}_{4} \cdot \mathrm{ZnBr}_{2} \cdot \mathrm{Et}_{3} \mathrm{NHBr}$}

Table 1. Analytical data.

\begin{tabular}{|l|l|l|l|}
\hline \multicolumn{1}{|c|}{ Complex } & \% C & \multicolumn{1}{c|}{ \% H } & \multicolumn{1}{c|}{ N } \\
\hline A & $33.89(33.70)$ & $4.81(4.60)$ & $3.66(3.58)$ \\
\hline B & $26.50(26.70)$ & $5.88(5.65)$ & $4.41(4.28)$ \\
\hline C & $35.34(35.32)$ & $5.81(5.79)$ & $4.67(4.65)$ \\
\hline D & $32.06(32.05)$ & $6.05(6.03)$ & $4.67(4.65)$ \\
\hline E & $30.97(30.95)$ & $5.67(5.64)$ & $4.93(4.92)$ \\
\hline
\end{tabular}

The elemental analyses have been obtained from the Microanalyses Laboratory (University of Burgundy, DijonFrance). The infrared spectra have been obtained from the University of Caen-France using a Brucker FT-IR spectrometer. IR abbreviations: broad (br), very strong (vs), strong (s), medium (m), shoulder (sh).

The chemicals were obtained from ALDRICH Company from Germany and used as such.

\section{RESULTS AND DISCUSSION}

Let us consider the infrared data of the studied compounds:

$\mathbf{L}_{1}:(v O H+v N H) 2948(\mathrm{br}), \operatorname{vas}\left(\mathrm{COO}^{-}\right) 1704(\mathrm{~m}), 1665(\mathrm{~s}), \mathrm{vs}\left(\mathrm{COO}^{-}\right) 1321(\mathrm{~m}), \delta\left(\mathrm{COO}^{-}\right) 792(\mathrm{~m})$;

L2: vNH 2987 (br), vas $\left(\mathrm{COO}^{-}\right) 1650$ (s), vs $\left(\mathrm{COO}^{-}\right) 1348(\mathrm{~m}), \delta\left(\mathrm{COO}^{-}\right) 796(\mathrm{~m})$;

A: $(v \mathrm{OH}+v \mathrm{NH}) 2972(\mathrm{br}), \operatorname{vas}\left(\mathrm{COO}^{-}\right) 1603(\mathrm{~s}), v \mathrm{~s}\left(\mathrm{COO}^{-}\right) 1309(\mathrm{~m}), \delta\left(\mathrm{COO}^{-}\right)$799(s);

B: $(v O H+v N H) 3405(b r), 2976(b r), 2940(b r), v a s\left(\mathrm{COO}^{-}\right) 1665(\mathrm{~m}), v \mathrm{~s}\left(\mathrm{COO}^{-}\right) 1240(\mathrm{~m}), \delta\left(\mathrm{COO}^{-}\right)$805(m);

C: $(v O H+v N H) 2985(\mathrm{br}), v a s\left(\mathrm{COO}^{-}\right) 1600(\mathrm{vs}), v \mathrm{~s}\left(\mathrm{COO}^{-}\right) 1315(\mathrm{~m}), \delta\left(\mathrm{COO}^{-}\right) 800(\mathrm{~s})$;

D: $(v O H+v N H) 3387(b r), 2982(b r), v a s\left(\mathrm{COO}^{-}\right) 1608(\mathrm{~s}), v s\left(\mathrm{COO}^{-}\right) 1312(\mathrm{~m}), \delta\left(\mathrm{COO}^{-}\right) 794$ (s);

E: $(v O H+v N H) 2984(\mathrm{br}), \operatorname{vas}\left(\mathrm{COO}^{-}\right) 1633(\mathrm{sh}), 1604(\mathrm{~s}), v \mathrm{~s}\left(\mathrm{COO}^{-}\right) 1315(\mathrm{~m}), \delta\left(\mathrm{COO}^{-}\right) 799(\mathrm{~s})$.

We will just consider the complex-anions for proposing the following structures. From the infrared data we suggest:

- For A, a discrete structure with a zinc centre chelated by three anions (Figure 1): the environment around the $\mathrm{Zn}$ centre is octahedral.<smiles>O=C1OC2(O1)O[C@H](O)[C@@H](O)O2</smiles>

Fig. 1. Proposed structure for A.

A hydrogen bonded dimer of the hydrogenoxalate anion has yet been reported by Braga et al [2]. For the first suggested structure we will consider the presence of this dimer and propose:

- A first dimeric one with two $\left[\mathrm{ZnBr}_{3}\right]$ ' monochelated by anions, the environment around the zinc centres being trigonal bipyramidal (Figure 2a).

- A second dimeric structure containing $\left[\mathrm{Zn}_{2} \mathrm{Br}_{6}\right]^{2-}$ with two bridging bromo atoms chelated by two anions, the environment around the $\mathrm{Zn}$ centres being octahedral (Figure $2 \mathrm{~b}$ ).

In these two structures the four water molecules are considered lattice. 


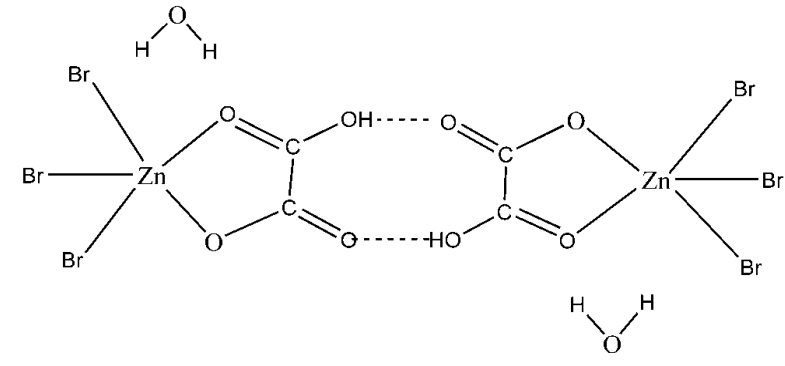

a)

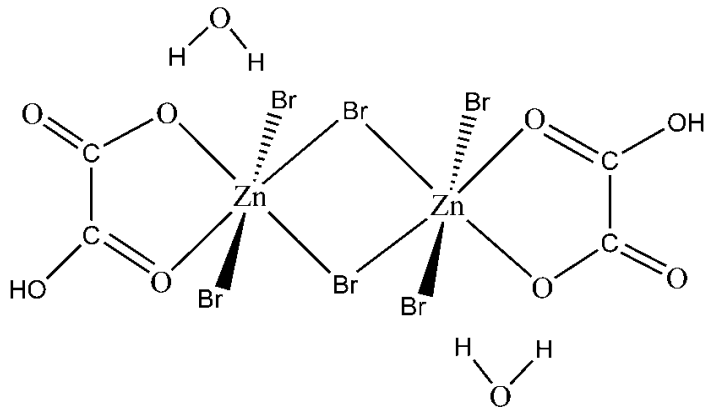

b)

Fig. 2. Proposed structures for $\mathbf{B}$.

The structure of $\mathbf{C}$ is deduced from the one of $\mathbf{A}$ on adding one molecule of $\mathrm{Et}_{3} \mathrm{NHBr}$. Two cases are possible:

- The $\mathrm{Br}$ atom coordinates the $\mathrm{Zn}$ centre leading to an heptacoordinated $\mathrm{Zn}$ centre, a monocapped octahedral environment (Figure 3a).

- $\quad$ The $\mathrm{Et}_{3} \mathrm{NHBr}$ molecule is inserted in the holes of the structure of $\mathbf{A}$ without coordination the zinc centre remaining in an octahedral environment (Figure 3b).

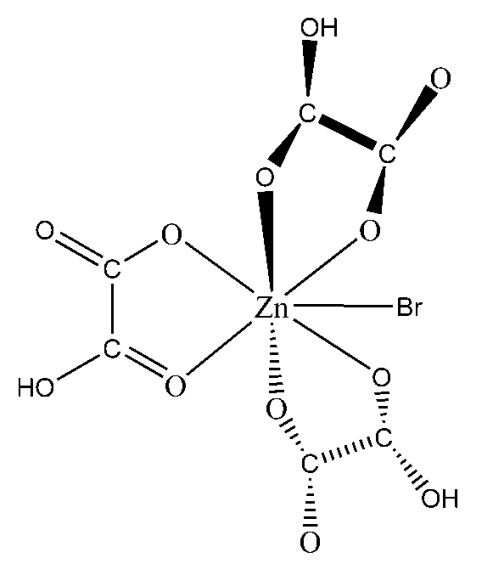

a)<smiles>O=C1O[Ge]2(O[C@@H]1O)O[C@H](O)[C@@H](O)O2</smiles>

b)

Fig. 3. Proposed structures for $\mathbf{C}$

For $\mathbf{D}$, we suggest a structure with two mononuclear metallic components (Figure 4):

- A first metallic component $\left[\mathrm{Zn}\left(\mathrm{C}_{2} \mathrm{O}_{4}\right)_{2}\right]^{2-}$ with a zinc centre monochelated by two anions, the environment around the $\mathrm{Zn}$ centre being tetrahedral.

- $\quad$ The second one being $\left[\mathrm{ZnBr}_{3} \mathrm{EtOH}\right]$ with a tetrahedral environment around the zinc centre.<smiles></smiles>

Fig. 4. Proposed structure for $\mathbf{D}$.<smiles>O=C1O[Ge]2(OC1O)O[C@H](O)[C@H](O)O2</smiles>

Fig. 5. Proposed structure for $\mathbf{E}$. 
The structure of $\mathbf{E}$ is deduced from the one of $\mathbf{D}$ on withdrawing the EtOH molecule leading to a trigonal environment around the second component zinc centre (Figure 5).

For all these structures, $\mathrm{OH}$ groups and the cation may be considered as involved in hydrogen bonding leading to supramolecular architectures.

\section{CONCLUSIONS}

The complexes studied in this work have discrete structures with monochelating anions. The environments around zinc centres being trigonal, trigonal bipyramidal, tetrahedral, octahedral or monocapped octahedral. When extra hydrogen bonds are considered, supramolecular architectures may be obtained.

\section{ACKNOWLEDGMENTS}

We thank to the Dr. Laurent Plasseraud (University of Burgundy, Dijon-France) and Dr. Jocelyne Levilain (University of Caen, France) for equipment support.

\section{REFERENCES}

[1] Hathaway, B.J., Comprehensive coordination chemistry (Editors: Wilkinson,G. ,Gillard, R.D., McCleverty, J.A.), 1st ed., Chapter 53, Pergamon Press, Oxford, vol. 5, 1987, p. 413.

[2] Braga, D., Eckert, M., Fraccastoro, M., Maini, L., Grepioni, C., Caneschi, A., Sessoli, R., The hydrogene oxalate anion allows one dimensional columar aggregation of organometallic sandwich cations, New Journal of Chemistry, no. 26, 2002, p. 1280-1286.

[3] Sow, Y., Diop, L., Stievano, L., $\mathrm{C}_{2} \mathrm{O}_{4}\left(\mathrm{SnPh}_{3}\right)_{2} .2 \mathrm{SnPh}_{3} \mathrm{OH}$ and $2 \mathrm{C}_{2} \mathrm{O}_{4}\left(\mathrm{SnPh}_{3}\right)_{2} . \mathrm{SnPh}_{3} \mathrm{OH} .2 \mathrm{H}_{2} \mathrm{O}$ : Synthesis and spectroscopic characterization, Physical and Chemical News, no. 72, 2014, p. 94-97.

[4] Gueye, N., Diop, L., Molloy, K. C., Kociok-Kohn, G., Bis(dicyclohexylammonium) $\mu-o x a l a t o-$ $\mathrm{k}^{4} \mathrm{O}^{1}, \mathrm{O}^{2}, \mathrm{O}^{1}, \mathrm{O}^{2}$-bis[aqua(oxalato- $\mathrm{k}^{2} \mathrm{O}^{1}, \mathrm{O}^{2}$ ) diphenylstannate(IV), Acta Crystallographica, E66, 2010, p. m1645m1646.

[5] Diasse-Sarr, A., Diop L., Mahon, M.F, Molloy, K.C.: X ray structure of $\mathrm{SnMe}_{3} \mathrm{SeO}_{3}\left[\mathrm{SnMe}_{3}\left(\mathrm{H}_{2} \mathrm{O}\right)\right]$, Main Group Metal Chemistry, no. 20, 1997,p. 223-230.

[6] Diop, L., Mahieu, B., Mahon, M. F., Molloy, K.C., Okio, K.Y.A., Bis(triphenyltin) oxalate, Applied Organometallic Chemistry, vol. 17, no. 11, 2003, p. 881-882.

[7] Diop, M.B., Diop, L., Phosphato and phosphonato adducts: synthesis and spectroscopic study, Scientific study \& Research-Chemistry \& Chemical Engineering, Biotechnology, Food Industry, vol. 15, no. 1, 2014 , p. 075-079.

[8] Ma, C., Han, Y., Zhang, R., Wang, D.: Self-assembly of diorganotin(IV) moieties and 2- pyrazinecarboxylic acid: Syntheses, characterizations and crystal structures of monomeric, polymeric trinuclear macrocyclic compounds, Dalton Transactions, 2004, p. 1832-1840.

[9] Gabe, E.J., Lee, F.L., Khoo, L.E., Smith, F.E., Chlorotriphenyl(quinolinium-2-carboxylati)tin(IV) monohydrate, Inorganica Chimica Acta, vol. 105, 1985, 103-106. 